\title{
Menelaah Pesan Pemerintah terkait Krisis Covid-19 di Media Sosial
}

\author{
Dewa Ayu Diah Angendari \\ Universitas Gadjah Mada \\ dewaayu@ugm.ac.id
}

Diterima : 16 Juni 2021

Disetujui : 5 Agustus 2021

Diterbitkan : 21 Agustus 2021

\begin{abstract}
Abstrak
Saat krisis kesehatan Covid-19 merebak tingkat ketidakpastian di masyarakat semakin tinggi. Pemerintah memiliki tanggungjawab untuk mengurangi ketidakpastian dengan memberikan pesan yang tepat kepada publik terdampak. Di Indonesia, Kementerian Kesehatan (Kemenkes) dan satuan gugus tugas Covid-19 (Satgas Covid-19) menjadi dua instansi yang secara aktif memberikan informasi terkait Covid-19. Penelitian ini bertujuan untuk menjelaskan secara deskriptif pesan yang disampaikan oleh kedua instansi terkait dengan Covid-19 melalui metode konten analisis. Hasil penelitian menemukan bahwa baik Kemenkes maupun Satgas Covid-19 memberikan penekanan pada pesan terkait upaya yang dilakukan pemerintah untuk menangani penyebaran Covid-19, perkembangan angka kasus, dan anjuran adopsi protokol kesehatan. Namun, kedua instansi tidak memberi porsi yang cukup terhadap pesan yang menjelaskan situasi krisis yang sedang dan ekspresi simpati kepada publik. Padahal penjelasan terkait situasi dapat mendorong publik untuk mengadopsi anjuran pemerintah, sementara ekspresi simpati diperlukan dalam situasi krisis untuk memberi rasa aman di tengah ketidakpastian.
\end{abstract}

Kata Kunci: pesan, komunikasi krisis, media sosial

\begin{abstract}
As the Covid-19 health crisis spreads, the level of uncertainty in the community is getting higher. The government has a responsibility to reduce uncertainty by providing the right message to the affected public. In Indonesia, the Ministry of Health (Kemenkes) and the Covid-19 task force (Task Force Covid-19) became two agencies that actively provide information related to Covid-19. This research aims to descriptively explain the message conveyed by both agencies related to Covid-19 through content analysis. The study results found that both the Ministry of Health and the Covid-19 Task Force emphasized messages related to the efforts made by the government to deal with the spread of Covid-19, the development of case numbers, and the recommendation of the adoption of health protocols. However, the two agencies did not give enough portions to the message explaining the current crisis and sympathy to the public. Explanations of the situation can encourage the public to adopt government advice, while expressions of sympathy are needed in crises to provide a sense of security amid uncertainty.
\end{abstract}

Keywords: message, crisis communication, social media

\section{PENDAHULUAN}

Saat ini, dunia termasuk Indonesia sedang dihadapkan pada krisis kesehatan dengan merebaknya wabah coronavirus disease (selanjutnya disebut Covid-19). Covid-19 secara 
resmi dikategorikan sebagai pandemi oleh WHO di tanggal 11 Maret 2020 (WHO, 2020). American Industrial Hygiene Association dalam Walaski (2011) mendefinisikan pandemi sebagai wabah penyakit yang memicu infeksi pada manusia secara simultan di seluruh dunia. Pandemi memicu krisis karena melibatkan penyakit yang disebabkan oleh virus yang belum pernah ada sehingga belum diantisipasi oleh imun manusia, menginfeksi banyak orang, menyebabkan kewalahan sektor kesehatan, serta menyebabkan disrupsi masal pada institusi pemerintahan. Kasus pandemi terakhir yang diumumkan oleh WHO adalah wabah H1N1 pada tahun 2009 (Westman, 2020).

Di Indonesia sendiri, Pemerintah pertama kali mengumumkan kasus positif covid-19 pada 2 Maret 2020 (Pranita, 2020). Dua instansi pemerintah yang menjadi motor informasi adalah Kementerian Kesehatan (Kemenkes) dan Badan Nasional Penanggulangan Bencana (BNPB) RI. Kemenkes secara rutin menggelar jumpa pers untuk memberi informasi terbaru tentang perkembangan kasus Covid-19, sementara BNPB ditunjuk sebagai ketua gugus tugas nasional Covid-19.

Liu et al. (2016) mengungkapkan bahwa krisis yang berkaitan dengan pandemi seringkali diasoasikan dengan tingkat ketidakpastian yang tinggi. Ketidakpastian akan menyebabkan krisis, jumlah individu yang terinfeksi dan korban jiwa, respon yang dapat diambil oleh individu untuk melindungi diri mereka, serta kapan krisis akan berakhir. Dalam kondisi krisis, pemerintah wajib untuk merespon krisis dan bertanggung jawab untuk pemulihan pasca krisis dengan menyediakan informasi (Atkinson, 2014; Lim et al., 2017).

Komunikasi yang dilakukan semasa krisis bertujuan untuk mencegah atau meminimalisir dampak yang dapat dirasakan organisasi, mempertahankan organisasi, serta memperbaiki citra organisasi Coombs (2010). Sementara dalam krisis kesehatan seperti pandemi, komunikasi krisis memiliki tujuan tambahan, yakni mengajak publik mengadopsi pola hidup sehat untuk menjadi kebiasaan jangka panjang (Lim et al., 2017).

Untuk mencapai tujuan tersebut, organisasi dapat memberikan beberapa jenis informasi terhadap publik terdampak Sturges (1994) dalam Coombs (2010) menjelaskan terdapat 3 (tiga) jenis pesan yang dapat diberikan oleh organisasi ketika menghadapi krisis, yaitu instructing information, adjusting information, dan internalizing information. Jenis pesan yang pertama, instructing information, memberikan informasi kepada publik yang terdampak krisis mengenai tindakan yang dapat diambil oleh publik ketika krisis berlangsung. Pesan yang disampaikan dapat berupa informasi mengenai apa krisis yang sedang dihadapi, dimana dan mengapa krisis terjadi, serta bagaimana menghadapinya. Selanjutnya, adjusting information berisikan informasi yang membantu publik untuk menghadapi krisis secara psikologis. Organisasi menginformasikan pesan berisi corrective action atau langkah yang sedang mereka lakukan untuk meminimalisir dampak krisis saat ini dan potensi terjadinya krisis yang berulang di masa mendatang. Tujuan dari jenis pesan ini adalah memberikan rasa aman secara psikologis bagi publik karena publik mempersepsikan bahwa krisis sudah berada di bawah kontrol organisasi. Jenis yang terakhir, internalizing information digunakan untuk menyelamatkan reputasi organisasi. Pesan ini disampaikan ketika kurva krisis sudah melandai dan bertujuan untuk memperbaiki hubungan dengan stakeholder.

Dalam konteks pandemi, Lim et al. (2017) berpendapat bahwa jenis pesan yang disampaikan akan berbeda dengan situasi krisis lain. Pesan yang berisikan instructing dan 
adjusting information saling melengkapi di setiap tahapan krisis. Sebagai contoh, instructing dan adjusting information secara bersamaan dapat digunakan difase awal dan ketika pandemi merebak untuk menjawab dan mengelola emosi publik. Sementara internalizing information tidak menjadi prioritas karena kesehatan publik lebih penting dibandingkan reputasi organisasi. Sementara Model Crisis and Emergency Risk Communication (CERC) yang dipublikasikan oleh Center for Disease Control and Prevention (CDC) menyebut ada empat jenis pesan yang sebaiknya disampaikan organisasi, yaitu 1) ekspresi simpati kepada publik terdampak, 2) penjelasan atas risiko yang diakibatkan krisis, 3) tindakan yang dapat dilakukan untuk meminimalir dampak krisis, serta 4) upaya organisasi dalam mengantisipasi dampak dan risiko krisis (Seeger et al., 2009).

Dalam perkembangannya, penyampaian pesan dalam komunikasi krisis tidak hanya dilakukan melalui media tradisional, namun juga pemanfaatan media sosial. Hal ini dikarenakan media sosial mampu menyediakan informasi terbaru, dapat diakses sewaktuwaktu, menyediakan peluang kolaborasi dengan pihak lain yang menghadapi isu serupa untuk membantu penyebaran pesan, dan merupakan rich media yang mampu menjelaskan berbagai pesan kompleks (Austin et al., 2012; Klyueva, 2009; Lim et al., 2017; Schmalzried et al., 2012). Seringkali individu yang terkena dampak langsung ataupun memiliki perhatian atas suatu krisis mencari informasi yang spesifik dan dapat dipercaya melalui kanal media resmi yang dimiliki oleh pemerintah, baik website ataupun social networking sites (Schmalzried et al., 2012; Faustina dalam Vos \& Buckner, 2016). Pengembangan pesannya pun tidak hanya dilakukan oleh organisasi ataupun pemerintah, namun juga melalui buzzer lewat kampanye yang terencana (Putra \& Irwansyah, 2020).

Penggunaan media sosial oleh pemerintah untuk komunikasi krisis telah beberapa kali menjadi topik riset, baik yang terkait praktik penggunaan media sosial secara umum (Austin et al., 2012; Eriksson \& Olsson, 2016; Lin et al., 2016; Macias et al., 2009; Zhu et al., 2017), spesifik terkait dengan krisis kesehatan (Ratzan \& Moritsugu, 2014; Roberts \& Veil, 2016; Vos \& Buckner, 2016), hingga ulasan konseptual (Liu et al., 2016). Namun, Olsson (2014) mengkritisi bahwa mayoritas studi terkait komunikasi krisis berfokus pada aspek mempertahankan dan memperbaiki citra organisasi, namun hanya sedikit literatur yang melihat aspek terkait substansi pesan yang diberikan oleh organisasi. Hal senada juga ditemukan dalam riset terkait komunikasi krisis Indonesia. Studi terkait penggunaan media sosial oleh pemerintah untuk komunikasi krisis lebih banyak berbicara tentang citra organisasi atau strategi komunikasi yang dilakukan organisasi secara umum (Fajri \& Mawadati, 2018). Untuk itu, penelitian ini berusaha untuk mengisi gap yang ada melalui pertanyaan penelitian, yakni 1) Pesan apa yang disampaikan pemerintah terkait krisis melalui media sosial yang dimilikinya ; 2) Bagaimana pemanfaatan media sosial oleh pemerintah dalam situasi krisis?

Penelitian ini bertujuan untuk menganalisis pesan yang disampaikan pemerintah terkait pandemi Covid-19 melalui kanal media sosial yang dimilikinya serta pemanfaatannya. Menggunakan kerangka pesan dalam komunikasi krisis oleh Sturges (1994) dan Lim et. al (2017), tulisan ini menemukan bahwa mayoritas pesan yang diberikan oleh pemerintah fokus pada berbagai langkah penanganan yang sudah, sedang, dan akan dilakukan oleh pemerintah (adjusting information) serta instruksi untuk mengadopsi protokol kesehatan (instructing 
information). Padahal publik juga perlu diberikan informasi terkait krisis yang tengah dihadapi (sensemaking) dan simpati untuk mengubah perilaku. Peneliti juga mengidentifikasi bahwa pesan yang disampaikan oleh kedua instansi tersebut tergolong konsisten karena memiliki fokus pesan yang sama di kanal media sosialnya. Konsistensi ini dibutuhkan untuk mencegah banjir informasi sekaligus memberikan opsi atas informasi kepada publik. Sebagai limitasi. Peneliti membatasi kanal media sosial menjadi dua, yakni website dan twitter. Sementara akun pemerintah yang menjadi objek penelitian adalah akun resmi Kemenkes RI dan Satuan Gugus Tugas Covid-19 (selanjutnya disebut Satgas Covid-19).

\section{METODOLOGI PENELITIAN}

Riset ini menggunakan metode konten analisis karena merupakan metode penelitian yang berfokus pada pesan dengan karakteristik sistematis dan objektif sehingga tepat untuk menjawab pertanyaan penelitian. Jenis data berupa rilis berita di website Kemenkes dan Satgas Covid-19 Kedua dan tweet yang dipublikasikan di Twitter Kemenkes (@KemenkesRI) dan Satgas Covid-19 (@BNPB_Indonesia). Tweets yang dianalisis dibatasi pada konten yang secara langsung disampaikan oleh organisasi. Thread atau tweet yang terkoneksi pada satu tema tertentu yang dikeluarkan oleh satu akun akan dihitung sesuai jumlah tweet-nya. Konten balasan untuk pengikut (followers), konten ulangan (retweet), atau konten yang disukai (like) tidak dimasukkan sebagai unit analisis. Selanjutnya, kategorisasi akan dilakukan terhadap data yang berhasil dikumpulkan.

Sebagai limitasi, data yang akan diambil merupakan data yang tersedia sejak Status Tanggap Darurat bencana diumumkan yakni 29 Februari hingga tanggal 29 Mei 2020. Total rilis berita yang dikumpulkan berjumlah 493 berita dengan detail rilis berita Kemenkes sejumlah 150 buah $(n=151)$ dan gugus tugas sejumlah 342 buah $(n=342)$. Sementara total tweet yang dikumpulkan berjumlah 2709 tweet dengan detail tweet Kemenkes sejumlah 1370 tweet $(\mathrm{n}=1370)$ dan gugus tugas sejumlah 1339 tweet $(\mathrm{n}=1339)$.

Penelitian ini menggunakan kategorisasi unit analisis Berelson, yakni rilis berita yang terdapat di website dan tweet yang diambil dari Twitter resmi pemerintah. Instrumen coding untuk rilis berita dan tweet terdiri atas tanggal, judul rilis, jenis pesan, dan variabel pesan oleh Sturges (1994). Selanjutnya, peneliti merancang protokol coding untuk melihat variabel yang diteliti dengan definisi dan contoh dari setiap variabel. Semua indikator diberikan kode berdasarkan keberadaan pesan yang mengandung variabel yang diteliti dengan angka 1 (ada variabel) dan angka 0 (tidak ada variabel). Dalam rilis berita, jika ditemukan satu paragraf yang mengandung salah satu variabel, maka keseluruhan rilis berita tersebut ditandai dengan angka 1. Rilis berita dan tweet yang berhasil dikumpulkan di-coding oleh dua asisten peneliti yang secara mandiri melakukan coding terhadap rilis berita dan tweet. Masing-masing coder sebelumnya telah dilatih selama 60 menit untuk memahami penelitian, variabel, dan cara melakukan coding. Peneliti juga menyiapkan coding protocol yang berisikan kategorisasi, sub kategori, dan contoh informasi yang masuk pada masing-masing sub kategori. Hal ini ditujukan untuk memastikan pemahaman yang sama antar coder. Selanjutnya, peneliti kemudian menyiapkan dokumen coding untuk diisi oleh dua coder tersebut.

Untuk melihat reliabilitasnya, penelitian ini menggunakan perhitungan Holsti's intercoder reliability. Rilis berita dan tweet yang sudah di-coding kemudian dipilih dengan 
menggunakan convenience systematic random sampling. Peneliti memilih 50 rilis berita dan 50 tweet. Setelahnya, didapatkan angka koefisien realibilitas 0.88 untuk tweet dan 0.85 untuk rilis berita. Berdasarkan perhitungan Holsti, analisis penelitian ini dianggap dapat dipercaya sehingga penelitian dapat dilanjutkan.

Analisis dilakukan terhadap keseluruhan total tweet dan rilis berita, sehingga akan menggunakan data deskriptif dan bukan analisis statistik. Kategorisasi yang digunakan untuk menganalisis jenis pesan menggunakan konsep yang Sturges (1994) dan CDC. Kategorisasi yang pertama berdasarkan jenis pesan yang dipaparkan oleh Sturges (1994) dibagi menjadi tiga kategori, yakni instructing information, adjusting information, dan internalizing information. Kategori instructing information memberikan informasi kepada publik yang terdampak krisis mengenai tindakan yang dapat diambil oleh publik ketika krisis berlangsung. Kategori ini diberikan pada pesan yang memberikan informasi dasar terkait Covid-19, seperti penjelasan tentang Covid-19, gejala penyakit, jumlah orang yang terinfeksi pandemi, jumlah korban jiwa, penyebaran virus, pengembangan vaksin, ketersediaan pelayanan medis, hingga apa yang harus dilakukan oleh publik untuk meminimalisir risiko tertular penyakit.

Kategori adjusting information berisikan informasi yang membantu publik untuk menghadapi krisis secara psikologis. Kategori ini diberikan pada pesan yang berisikan corrective action dari pemerintah dan mengekspresikan simpati kepada korban. Informasi yang dimaksud seperti kesiapan pelayanan kesehatan, kesiapan pemerintah, kebijakan yang diambil untuk mengantisipasi dampak pandemi. Sementara kategori internalizing information digunakan untuk menyelamatkan reputasi organisasi. Kategori ini diberikan pada pesan seperti komparasi penanganan pandemi di Indonesia dibandingkan dengan negara lain, rekam jejak pemerintah dalam menangani krisis yang pernah terjadi.

\section{HASIL DAN PEMBAHASAN (12 pt bold)}

Berdasarkan data yang diambil dari website Kemenkes, terdapat 142 rilis berita terkait Covid-19 selama periode 29 Februari hingga 29 Mei 2020. Sementara untuk satgas Covid-19, terdapat 351 rilis berita yang berhasil dikumpulkan.

Tabel 1. Jenis pesan rilis berita Kemenkes RI dan Gugus Tugas Covid-19

\begin{tabular}{lcc}
\hline Jenis pesan & $\begin{array}{l}\text { Kemenkes } \\
\mathrm{RI}(\mathrm{n}=142)\end{array}$ & $\begin{array}{l}\text { Satgas Covid- } \\
19(\mathrm{n}=351)\end{array}$ \\
\hline Instructing Information & $95(0.67)$ & $171(0.49)$ \\
Penjelasan terkait Covid-19 & 8 & 16 \\
Angka pasien Covid-19 & 57 & 53 \\
Instruksi meminimalisir risiko & 9 & 89 \\
Kebijakan PSBB & 21 & 13 \\
Adjusting Information & $43(0.31)$ & $152(0.43)$ \\
Penanganan oleh pemerintah & 40 & 143 \\
\hline
\end{tabular}




\begin{tabular}{lll}
\hline Empati & 3 & 9 \\
Internalizing Information & $\mathbf{4}(\mathbf{0 . 0 2})$ & $\mathbf{2 8}(\mathbf{0 . 0 8})$
\end{tabular}

Sumber: Data Olahan Peneliti, 2020

Berdasarkan hasil coding, terlihat bahwa mayoritas jenis pesan yang diberikan oleh Kemenkes selama krisis berlangsung adalah instructing information (0.65) disusul oleh adjusting information (0.31) dan hanya sedikit pesan dengan internalizing information (0.02). Jika dilihat lebih detail, berita terkait angka pasien Covid-19 merupakan jenis berita yang paling sering diunggah. Selebihnya, mayoritas pesan berisikan tentang penanganan Covid-19 oleh pemerintah dan penetapan kebijakan pembatasan sosial berskala besar (PSBB) di berbagai daerah di Indonesia. Senada dengan rilis berita oleh Kemenkes, rilis berita di laman website gugus tugas covid-19 juga mayoritas diisi oleh instructing information $(0,49)$, adjusting information (0.43), dan internalizing information (0.08). Namun, berbeda dengan Kemenkes, rilis berita oleh gugus tugas covid-19 lebih banyak bercerita tentang penanganan oleh pemerintah, yang disusul dengan instruksi untuk meminimalisir risiko penularan, dan angka pasien covid-19.

Melihat data dari rilis berita, terdapat persamaan dan perbedaan isi pesan antara rilis berita oleh Kemenkes dan satgas Covid-19. Kedua instansi memadukan penggunaan 3 jenis pesan dalam rilis berita dan didominasi oleh pesan berjenis instructing information. Namun, jika dilihat lebih detail, dalam kategori instructing information, rilis berita yang dikeluarkan oleh Kemenkes lebih banyak berbicara tentang angka pasien Covid-19, baik pasien sembuh, tambahan kasus harian, hingga jumlah pasien meninggal. Rilis berita Kemenkes juga banyak berisi tentang penetapan Pembatasan Sosial Berskala Besar (PSBB), daerah mana saja di Indonesia yang dapat dan tidak dapat menerapkan PSBB. Sementara gugus tugas covid-19 lebih berfokus instruksi kepada masyarakat untuk menghindari penularan serta angka pasien Covid-19.

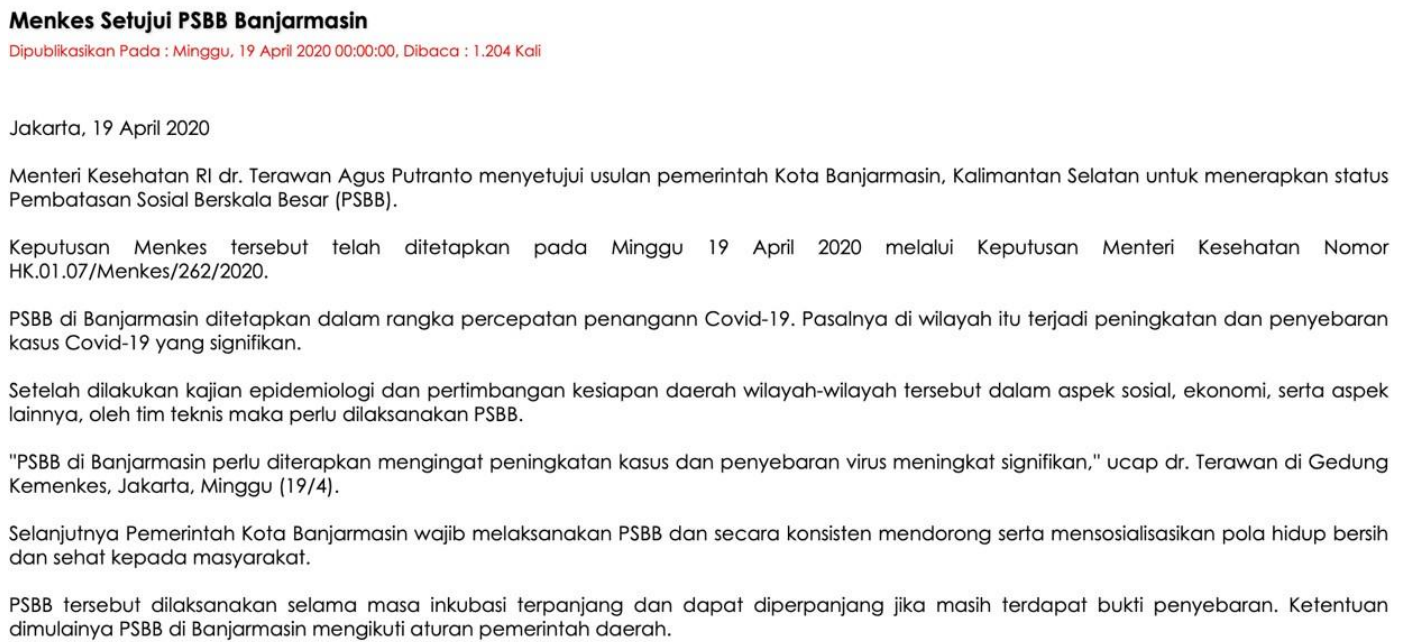

Gambar 1. Berita pada laman website Kemenkes RI tentang persetujuan pemberlakuan PSBB dari (Kementerian Kesehatan Republik Indonesia, 2020a) 
Temuan tersebut mengindikasikan bahwa terdapat fokus pesan yang berbeda antar dua lembaga pemerintah tersebut. Meskipun sama-sama berisikan instructing information, namun Kemenkes lebih fokus pada pemaparan deskriptif kurva pasien dan kebijakan PSBB yang memang berada di bawah kendali Kemenkes. Sementara gugus tugas covid-19 menekankan promosi kesehatan untuk masyarakat. Kedua instansi ini belum cukup memberikan informasi terkait Covid-19 itu sendiri. Angka pemberitaan terkait yang memberi informasi dasar tentang apa itu covid-19, bagaimana penularannya, serta risiko apa yang dibawa terlihat jomplang jika dibandingkan angka kasus dan instruksi pencegahan.

\section{Pemerintah Segera Distribusikan 105.00o APD \\ (1) 22 Mar 2020}

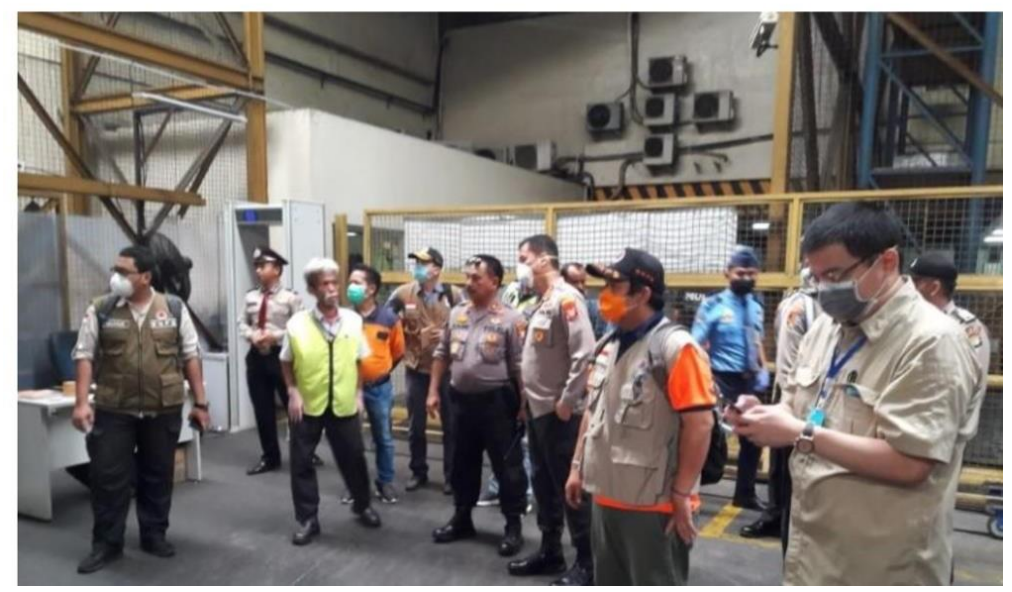

Gambar 2. Berita pada laman website Satgas Covid-19 tentang penanganan pandem Covid-19 oleh pemerintah, dari (Satuan Tugas Penanganan COVID-19, 2020)

Mengutip dari studi tentang komunikasi krisis saat pandemi H1N1 (Reynolds \& Seeger dalam Vos \& Buckner, 2016), komunikasi krisis akan efektif apabila individu diberikan pemahaman atas situasi yang dihadapi sehingga individu dapat mengevaluasi respon apa yang perlu diambil untuk mengantisipasi keadaan (sensemaking). Virus ini memang merupakan jenis baru virus influenza sehingga belum banyak data sains yang dapat dibagi ke publik. Namun, dalam komunikasi krisis di masa pandemi, membagikan informasi terkait apa krisis yang dihadapi oleh publik menjadi penting untuk mengurangi ketidakpastian yang timbul. Tanpa penjelasan yang memadai, informasi deskriptif tentang angka dikhawatirkan justru malah meningkatkan ketidakpastian yang ada. Selain itu, tanpa penjelasan terkait penyakit yang sedang dihadapi, akan sulit bagi publik untuk mengadopsi anjuran promosi kesehatan yang diberikan oleh pemerintah.

Sementara untuk kategori adjusting information, baik Kemenkes maupun satgas covid19 sama-sama menitikberatkan pada penanganan yang dilakukan oleh pemerintah. Contoh pesan ini misalnya kesiapan alat pelindung diri (APD) bagi tenaga kesehatan (nakes) atau jumlah fasilitas kesehatan (faskes) yang memadai untuk menampung pasien Covid-19. Sementara pesan yang menyampaikan simpati kepada publik jumlahnya sangat minimal. Contoh pesan yang mengandung simpati misalnya ucapan duka dan santunan pemerintah 
terhadap nakes yang berpulang karena Covid-19. Dari rilis berita yang dianalisis, tidak terdapat ekspresi simpati pemerintah terhadap publik luas yang terdampak, baik berupa belasungkawa atau apresiasi atas usaha yang dilakukan publik. Merujuk pada penelitian sebelumnya (Seeger et al., 2009; Shen, 2010), ekspresi simpati ke publik dapat mempengaruhi perilaku publik dan mendorong publik untuk mau mengikuti saran yang diberikan oleh pemerintah.

Data kedua yang diambil dari tweet menunjukkan hasil yang senada. Twitter dalam komunikasi krisis dapat menjadi perpanjangan tangan organisasi agar lebih cepat menyebarkan informasi untuk media dan individu penggunanya (Eriksson \& Olsson, 2016; McGuire et al., 2020). Kelebihan ini dapat menjadi amunisi bagi kedua instansi pemerintah untuk menjangkau publik dengan informasi secara lebih cepat dibandingkan rilis berita. Apalagi, baik Kemenkes maupun gugus tugas Covid-19 memiliki jumlah pengikut di atas 330 ribu pengikut. Hal ini tampaknya diantisipasi oleh tim media sosial kedua instansi karena keduanya secara aktif setiap harinya menyapa pengikut dan memunculkan informasi baru dengan kuantitas rerata antara 9 hingga 13 tweet setiap harinya. Dari sisi jumlah tweet yang dihasilkan setiap harinya, tampak Kemenkes lebih aktif dibandingkan gugus tugas Covid19.Informasi yang disampaikan pun beragam, dengan detail sebagai berikut:

Tabel 2. Jenis pesan Twitter Kemenkes RI dan Gugus Tugas Covid-19

\begin{tabular}{lll}
\hline Jenis pesan & $\begin{array}{l}\text { Kemenkes RI } \\
(\mathbf{n}=\mathbf{1 2 0 5})\end{array}$ & $\begin{array}{l}\text { Satgas Covid-19 } \\
(\mathbf{n}=\mathbf{8 2 7})\end{array}$ \\
\hline Instructing Information & $\mathbf{7 7 1 ( 0 . 6 4 )}$ & $\mathbf{4 1 6 ( 0 . 5 0 )}$ \\
\hline Penjelasan terkait Covid-19 & 232 & 33 \\
\hline Angka pasien Covid-19 & 304 & 100 \\
\hline Instruksi meminimalisir risiko & 147 & 226 \\
\hline Kebijakan PSBB & 88 & 57 \\
\hline Adjusting Information & $\mathbf{4 2 2 ( 0 . 3 5 )}$ & $\mathbf{4 0 2 ( 0 . 4 9 )}$ \\
\hline Penanganan oleh pemerintah & 402 & 385 \\
\hline Empati & 20 & 17 \\
\hline Internalizing Information & $\mathbf{1 2 ( 0 . 0 1 )}$ & $\mathbf{9 ( 0 . 0 1 )}$
\end{tabular}

Sumber: Data Olahan Peneliti, 2020

Merujuk pada hasil coding yang dapat dilihat di tabel 2, baik Kemenkes maupun satgas Covid-19 sama-sama memadukan instructing information dan adjusting information. Hanya saja, jika proporsi instructing information di tweet Kemenkes lebih dari setengah dari total pesan yang diberikan (0.64), proporsi instructing information dan adjusting information ada tweet gugus tugas Covid-19 cenderung berimbang. Sama seperti hasil coding data terkait rilis berita, Kemenkes fokus pada pesan terkait angka kasus dan usaha penanganan yang dilakukan oleh pemerintah untuk mengatasi pandemi. 


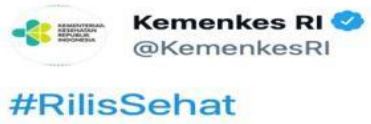

Gambar 3. Cuitan pada akun resmi Kemenkes RI tentang usaha penanganan Covid-19 yang dilakukan oleh pemerintah, dari (Kementerian Kesehatan Republik Indonesia, 2020b)

Pola yang sama juga ditemukan pada gugus tugas Covid-19. Hasil analisis tweet gugus tugas Covid-19 memperlihatkan bahwa fokus pesan yang ditekankan sama dengan fokus pesan pada rilis berita, yakni instruksi kepada masyarakat mengenai cara meminimalisir risiko dan usaha dilakukan oleh pemerintah.

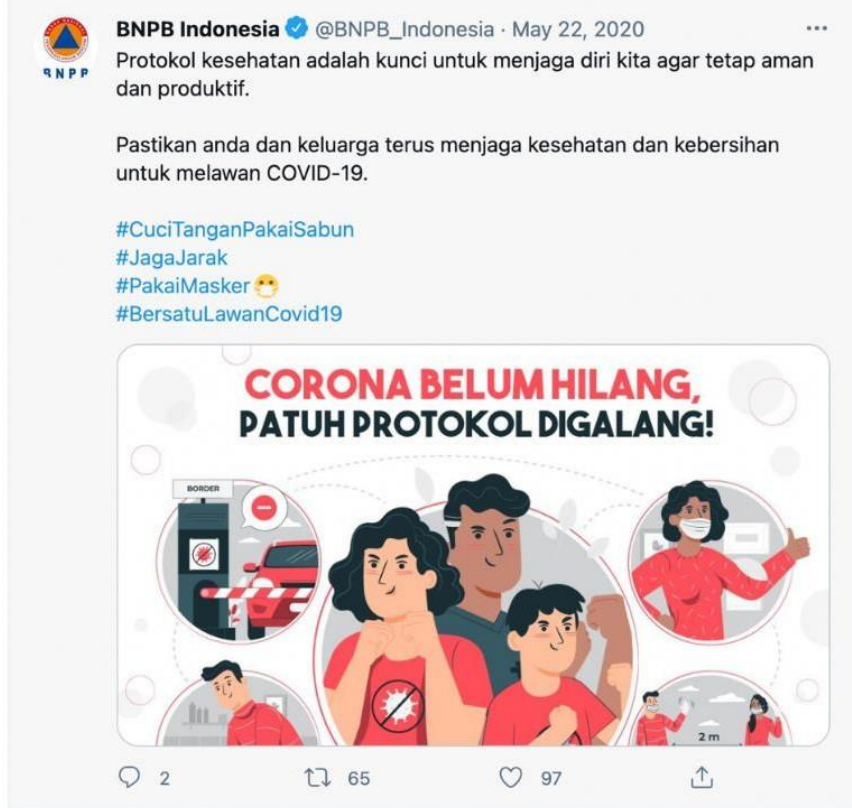

Gambar 4. Cuitan pada akun resmi Satgas Covid-19 tentang penjelasan dan instruksi untuk mematuhi protokol kesehatan, dari (Badan Nasional Penanggulangan Bencana, 2020) 
Selanjutnya, terkait dengan pengunaan media sosialnya sebagai saluran komunikasi krisis, Kemenkes RI dan satgas Covid-19 menerapkan pola yang sama dalam penentuan jenis pesan yang disampaikan ke publik. Keduanya memiliki fokus yang sama dengan rilis berita pada website. Penanganan pemerintah dan angka kasus Covid-19 menjadi yang dominan disampaikan oleh Kemenkes RI. Bahkan secara kuantitas jauh melebihi informasi lain seperti penjelasan tentang penyakit, instruksi untuk masyarakat, dan ungkapan simpati. Begitu juga dengan Satgas Covid-19. Pola pesan pada twitter sama dengan pola pesan yang ditemui di laman website mereka, yakni konten terkait penanganan pandemi oleh pemerintah dan instruksi terkait protokol kesehatan. Jumlah tweet ini jauh melampaui tweet tentang penjelasan penyakit dan ungkapan simpati.

Temuan dalam tulisan ini memberi gambaran bahwa baik Kemenkes maupun Satgas Covid-19 berusaha untuk menunjukkan berbagai upaya penanganan pandemi yang telah dilakukan oleh pemerintah (adjusting information). Pesan ini disampaikan melalui pemberian informasi kepada publik terkait berbagai kebijakan yang diambil oleh pemerintah, persiapan alat pelindung diri (APD), ketersediaan tenaga dan fasilitas kesehatan, perkembangan vaksin, hingga ketahanan pangan. Kemudian, kedua instansi juga secara konsisten memberikan informasi terkait statistik kasus dan instruksi untuk menaati protokol kesehatan (instructing information).

Menurut penelitian yang dilakukan oleh Lim, et. al (2017), penyampaian pesan pada krisis kesehatan harus menyeimbangkan porsi instructing dan adjusting information. Pesan bernada instructing information tidak hanya berisikan himbauan atau ajakan untuk melakukan Tindakan tertentu, tetapi juga penjelasan atas situasi krisis yang tengah dihadapi. Sementara adjusting information tidak hanya menekankan pada upaya penanganan yang dilakukan oleh organisasi, namun juga dukungan secara psikologis kepada publik terdampak.

Tulisan ini menemukan bahwa pemerintah melalui Kemenkes dan Satgas Covid-19 telah memberikan pesan bernada instructing dan adjusting information secara bersamaan. Namun, pesan yang mengandung instructing information lebih menekankan pada aspek himbauan untuk menaati protokol kesehatan. Sedangkan pesan yang berisikan penjelasan mengenai Covid-19 belum mendapat porsi yang cukup. Sementara itu, pesan yang mengandung adjusting information lebih banyak berbicara tentang usaha penanganan pandemi dilakukan oleh pemerintah dan hanya memuat sedikit dukungan atau simpati kepada publik terdampak.

Studi dari Vos \& Buckner (2016) terkait krisis kesehatan merekomendasikan bahwa komunikasi krisis dapat berjalan dengan efektif apabila publik memiliki pemahaman yang cukup atas situasi krisis yang dihadapi. Pemahaman atas situasi krisis mencakup pengetahuan terkait apa itu Covid-19, gejala penyakit, faktor risiko, hingga konsekuensi yang ditimbulkan. Dengan pemahaman ini, publik kemudian dapat menakar risiko yang mereka hadapi dan memilih tindakan yang dapat dilakukan untuk meminimalisir dampak krisis (sensemaking). Tanpa pemahaman yang cukup, pemerintah akan mengalami kendala untuk mempersuasi publik agar mengadopsi atau menaati protokol kesehatan.

Selain itu, pesan penting lain yang juga mendapat porsi yang cukup adalah pesan yang menunjukkan dukungan moral atau berisikan ekspresi simpati terhadap publik yang terdampak. Dukungan psikologis dapat meniminalisir kepanikan yang muncul akibat situasi krisis yang penuh dengan ketidakpastian. Berdasarkan hasil coding, ekspresi simpati dalam 
tweet Kemenkes dan Satgas Covid-19 hanya dimaknai sebagai pemberian insentif bagi tenaga kesehatan dan santunan bagi keluarga korban. Padahal ekspresi simpati juga bisa diwujudkan melalui rekognisi dan perhatian terhadap publik yang menderita karena dampak krisis dan menunjukkan bahwa pemerintah merasakan emosi yang dirasakan oleh publik (Bakker et al., 2018).

Jika dibandingkan antara penggunaan rilis berita dan tweet sesama instansi, Kemenkes dan gugus tugas covid-19 menunjukkan konsistensi dalam fokus pesan yang disampaikan. Baik melalui rilis berita dan tweet, Kemenkes banyak menyampaikan informasi terkait langkah penanganan yang diambil oleh pemerintah dan angka kasus pasien. Begitu juga dengan gugus tugas Covid-19. Di kedua media sosial yang dimilikinya, gugus tugas Covid-19 secara konsisten menyampaikan informasi tentang langkah pemerintah untuk menangani pandemi dan panduan perilaku hidup sehat yang dapat diterapkan oleh publik. Penyampaian pesan yang fokus dapat mencegah terjadinya banjir informasi yang justru dapat mengganggu fokus pesan utama yang ingin disampaikan.

Lebih lanjut, media sosial tidak hanya berfungsi sebagai alat untuk menyebarkan informasi, namun juga berkolaborasi dengan organisasi lain yang menghadapi permasalahan serupa untuk memberikan dan mempromosikan konten terkait pandemi (Lim et al., 2017). Selain komunikasi eksternal kepada publik, komunikasi dan kolaborasi antar kementerian dan lembaga negara tentunya diperlukan untuk menjaga konsistensi pesan, kredibilitas pemerintah, sekaligus secara optimal memanfaatkan kelebihan media sosial dalam situasi krisis seperti sekarang ini. Tujuan dari komunikasi krisis saat pandemi tidak hanya untuk mengurangi dampak dan ketidakpastian, menjaga citra organisasi, tetapi juga untuk mengajak publik untuk mengadopsi pola hidup sehat untuk jangka panjang.

\section{PENUTUP}

Berdasarkan analisis yang telah dilakukan, baik Kemenkes maupun Satgas Covid-19 fokus pada pesan terkait dengan berbagai upaya yang telah, sedang, dan akan dilakukan oleh pemerintah untuk menangangi dan menekan mata rantai penyebaran Covid-19 (adjusting information). Lebih lanjut, Kemenkes juga secara rutin memberi informasi terkait perkembangan statistik kasus, seperti jumlah penambahan pasien harian, pasien meninggal, dan pasien sembuh (instructing information). Sedangkan Satgas Covid-19 cenderung memberi penekanan pada anjuran agar publik mau melakukan protokol kesehatan, seperti menggunakan masker, menghindari kerumunan, dan mencuci tangan (instructing information). Kedua instansi memberikan sedikit porsi untuk menjelaskan situasi yang tengah dihadapi masyarakat, seperti penjelasan mengenai apa itu Covid-19, bagaimana penyebarannya, serta siapa yang berisiko tertular. Padahal penjelasan tersebut dapat membantu publik untuk mencerna krisis yang tengah dihadapi (sensemaking), memperkirakan risiko, serta mendorong untuk mengadopsi langkah-langkah yang dapat dilakukan untuk menimalisir dampak krisis. Selain itu, kedua instansi tersebut jarang menyampaikan ungkapan simpati kepada publik terdampak. Ungkapan simpati dalam situasi krisis dapat menenangkan dan memberikan rasa aman terhadap publik di tengah situasi yang penuh dengan ketidakpastian. 
Namun, penelitian ini tentunya memiliki beberapa limitasi yang diharapkan dapat diatasi pada riset lanjutan. Pertama, penelitian ini dilakukan dalam periode waktu yang cukup singkat dan krisis masih berjalan, yakni 29 Februari hingga 29 Mei 2020. Diperlukan riset lanjutan yang dapat mengidentifikasi jenis pesan dalam fase krisis yang berbeda, seperti pada masa awal krisis dan setelah pemerintah menerapkan new normal atau tatanan kebiasaan baru. Kedua, studi ini hanya menganalisis dua instansi pemerintah, yakni Kemenkes dan Satgas Covid-19. Padahal, pandemi Covid-19 merupakan krisis nasional yang dihadapi baik oleh pemerintah pusat sekaligus daerah. Media sosial tidak hanya dimanfaatkan oleh pemerintah pusat, tetapi juga daerah. Oleh karena itu, riset lanjutan dapat melihat jenis pesan yang dilakukan oleh pemerintah daerah. Hasil riset ini akan memberi gambaran yang lebih komprehensif terkait isi dan konsistensi pesan antar instansi pemerintah. Ketiga, dikarenakan keterbatasan sumber daya dan waktu, riset ini menggunakan konten analisis deskriptif dan hanya menganalisis teks. Padahal, baik rilis berita di website dan tweet tergolong rich media yang memungkinkan pemerintah untuk mengoptimalkan penggunaan visual dan audio dalam penyampaian pesan. Riset selanjutnya dapat mengikutsertakan teks, audio, dan visual sebagai sub unit analisis. Temuan dari riset tersebut tentunya akan membawa lebih banyak data sehingga analisis dapat dilakukan secara lebih mendalam.

\section{REFERENSI}

Atkinson, C. L. (2014). Crisis Communication in Dark Times: The 2011 Mouse River Flood in Minot, North Dakota. 21.

Austin, L., Fisher Liu, B., \& Jin, Y. (2012). How Audiences Seek Out Crisis Information: Exploring the Social-Mediated Crisis Communication Model. Journal of Applied Communication Research, 40(2), 188-207. https://doi.org/10.1080/00909882.2012.654498

Badan Nasional Penanggulangan Bencana. (2020). Corona Belum Hilang, Patuh Protokol Digalang. Tersedia dari: https://twitter.com/BNPB_Indonesia/status/1263805208959709184

Bakker, M. H., van Bommel, M., Kerstholt, J. H., \& Giebels, E. (2018). The influence of accountability for the crisis and type of crisis communication on people's behavior, feelings and relationship with the government. Public Relations Review, 44(2), 277286. https://doi.org/10.1016/j.pubrev.2018.02.004

Coombs, W. T. (2010). Conceptualizing Crisis Communication. In R. L. Heath \& H. D. O’Hair (Eds.), Handbook of Risk and Crisis Communication (1st ed., pp. 99-118). Routledge. https://doi.org/10.4324/9781003070726-6

Eriksson, M., \& Olsson, E.-K. (2016). Facebook and Twitter in Crisis Communication: A Comparative Study of Crisis Communication Professionals and Citizens. Journal of Contingencies and Crisis Management, 24(4), 198-208. https://doi.org/10.1111/14685973.12116

Fajri, C., \& Mawadati, S. (2018). MANAJEMEN KRISIS PEMERINTAH KABUPATEN KULON PROGO. Jurnal ASPIKOM, 3(4), 783. https://doi.org/10.24329/aspikom.v3i4.224 
Kementerian Kesehatan Republik Indonesia. (2020a). Menkes Setujui PSBB Banjarmasin.

Tersedia dari: https://www.kemkes.go.id/article/view/20042000003/menkes-setujuipsbb-banjarmasin.html

Kementerian Kesehatan Republik Indonesia. (2020b). Pemerintah Belum Rencanakan Relaksasi PSBB. Tersedia dari: https://twitter.com/KemenkesRI/status/1262769247836450818

Khan, G. F. (2015). The Government 2.0 utilization model and implementation scenarios. Information Development, 31(2), 135-149. https://doi.org/10.1177/0266666913502061

Klyueva, A. V. (2009). An integrated model of media selection in strategic communication campaigns. In That Matters to the Practice, 277.

Lim, R. S.-Q., Tan, E. Y., Lim, E. W., Aziz, N. B. A., \& Augustine. (2017). When a Pandemic Strikes. In L. Austin \& Y. Jin (Eds.), Social Media and Crisis Communication (1st ed., pp. 253-266). Routledge. https://doi.org/10.4324/9781315749068-19

Lin, X., Spence, P. R., Sellnow, T. L., \& Lachlan, K. A. (2016). Crisis communication, learning and responding: Best practices in social media. Computers in Human Behavior, 65, 601-605. https://doi.org/10.1016/j.chb.2016.05.080

Liu, B. F., Bartz, L., \& Duke, N. (2016). Communicating crisis uncertainty: A review of the knowledge gaps. Public Relations Review, 42(3), 479-487. https://doi.org/10.1016/j.pubrev.2016.03.003

Macias, W., Hilyard, K., \& Freimuth, V. (2009). Blog Functions as Risk and Crisis Communication During Hurricane Katrina. Journal of Computer-Mediated Communication, 15(1), 1-31. https://doi.org/10.1111/j.1083-6101.2009.01490.x

McGuire, D., Cunningham, J. E. A., Reynolds, K., \& Matthews-Smith, G. (2020). Beating the virus: An examination of the crisis communication approach taken by New Zealand Prime Minister Jacinda Ardern during the Covid-19 pandemic. Human Resource Development International, 23(4), 361-379. https://doi.org/10.1080/13678868.2020.1779543

Olsson, E.-K. (2014). Crisis Communication in Public Organisations: Dimensions of Crisis Communication Revisited: Dimensions of Crisis Communication Revisited. Journal of Contingencies and Crisis Management, 22(2), 113-125. https://doi.org/10.1111/1468-5973.12047

Pranita, E. (2020, November 5). Diumumkan Awal Maret, Ahli: Virus Corona Masuk Indonesia dari Januari [News]. Kompas.Id. https://www.kompas.com/sains/read/2020/05/11/130600623/diumumkan-awal-maretahli--virus-corona-masuk-indonesia-dari-januari

Ratzan, S. C., \& Moritsugu, K. P. (2014). Ebola Crisis-Communication Chaos We Can Avoid. Journal of Health Communication, 19(11), 1213-1215. https://doi.org/10.1080/10810730.2014.977680

Roberts, H., \& Veil, S. R. (2016). Health literacy and crisis: Public relations in the 2010 egg recall. Public Relations Review, 42(1), 214-218. https://doi.org/10.1016/j.pubrev.2015.07.013 
Satuan Tugas Penanganan COVID-19. (2020). Pemerintah Segera Distribusikan 105.000 $A P D$. Tersedia dari: https://covid19.go.id/p/berita/pemerintah-segera-distribusikan105000-apd

Schmalzried, H. D., Fleming Fallon, L., \& Harper, E. A. (2012). Assessing informational website communications during emergencies and disasters: Assessing informational website communications. International Journal of Nonprofit and Voluntary Sector Marketing, 17(3), 199-207. https://doi.org/10.1002/nvsm.1423

Seeger, M. W., Reynolds, B., \& Sellnow, T. L. (2009). Crisis and Emergency Risk Communication in Health Contexts: Applying the CDC Model to Pandemic Influenza. In R. L. Heath \& H. D. O'Hair (Eds.), Handbook of Risk and Crisis Communication (1st ed., pp. 493-506). Routledge. https://doi.org/10.4324/9781003070726-27

Shen, L. (2010). Mitigating Psychological Reactance: The Role of Message-Induced Empathy in Persuasion. Human Communication Research, 36(3), 397-422. https://doi.org/10.1111/j.1468-2958.2010.01381.x

Sturges, D. L. (1994). Communicating through Crisis: A Strategy for Organizational Survival. Management Communication Quarterly, 7(3), 297-316. https://doi.org/10.1177/0893318994007003004

Vos, S. C., \& Buckner, M. M. (2016). Social Media Messages in an Emerging Health Crisis: Tweeting Bird Flu. Journal of Health Communication, 21(3), 301-308. https://doi.org/10.1080/10810730.2015.1064495

Walaski, P. F. (2011). Risk and Crisis Communications: Methods and Messages. John Wiley \& Sons, Inc. https://doi.org/10.1002/9781118093429

Westman, N. (2020, November 3). WHO declares the outbreak of the new coronavirus is a pandemic-The Verge [News]. The Verge. https://www.theverge.com/2020/3/11/21156325/coronavirus-pandemic-who-declarescovid-19-outbreak-global-h1n1

WHO. (2020, April 27). Archived: WHO Timeline-COVID-19. https://www.who.int/news/item/27-04-2020-who-timeline---covid-19

Zhu, L., Anagondahalli, D., \& Zhang, A. (2017). Social media and culture in crisis communication: McDonald's and KFC crises management in China. Public Relations Review, 43(3), 487-492. https://doi.org/10.1016/j.pubrev.2017.03.006 